\title{
Water-Education as a Promoter of Education for Sustainable Development: Three Studies in Portuguese- Speaking African Countries
}

\author{
By Mafalda Franco Leitão ${ }^{1}$, Albino Cunha ${ }^{1}$, Manuela Malheiro Ferreira ${ }^{1}$
}

\begin{abstract}
The present study is based on research in teacher self-training in Education for Sustainable Development (Leitão, 2012). Water was the motivating theme. The priority of a fair distribution of water, guaranteeing the consumption, in quality and quantity, to all mankind and living beings is urgent. To respond to water-related sustainability challenges, people worldwide need to acquire "water literacy" about various aspects of water use and management in order to ensure safer water consumption and to contribute to Disaster Risk Reduction (DRR). Three case studies were carried out in schools in three African countries: Angola, Guinea-Bissau and Mozambique. A model of skills in education for sustainable development was applied (Sleurs, 2008). From the analysis of these case studies the theoretical assumptions of research were strengthened by the effective professional practice. But, on contrary, the results that the pillars of sustainable development presented in the basic research should be reviewed, placing the political dimension as transversal, thus strengthening education for sustainable development as fundamental for critical and responsible citizens of the present and of the future. This experience paves the way for future water-education and education for sustainable development projects; such as the follow-up of these three schools.
\end{abstract}

Keywords: Sustainable Development; Education for Sustainable Development; Water-education and Water Literacy; Case Study

\section{Introduction}

Nowadays, a global challenge was stilled: to be succeeding on a new sustainable development paradigm. Indeed, any environmental, social, economic or political problem belongs to only one region or country. So, development was always seen with global implications.

A question may be raised: What we want to be developed in a sustainable way? Whatever leads to the satisfaction of human needs, present and future, taking into account the Earth's capacities.

These consummations are of different types:

- Economic: employment, livelihood, housing, adequate access to consumer goods;

- Social, cultural and spiritual: including health, safety, education, equal opportunities, freedom of religious expression;

- Environmental: protection against environmental disasters, access to natural resources such as water, soil or air, and

- Political: freedom, peace, civic participation, among others.

After the World War II, especially from the 1950s onwards, the great improvements in 
the standard of living and quality of life of the populations of industrialized countries were brought about by a paradigm of economic development. Simultaneously, has emerged the biggest environmental impact of human history and the widening gap between populations of countries with different levels of industrialization.

From this point of view, it will be necessary accept the limits of an indefinite economic growth, and consequently the development of a new society, respectful of human being and the biosphere that surrounds it (Villenueve, 1998).

Furthermore, some argue that given the level reached by the ecological crisis, it would be not possible to have both economic development and environmental sustainability. Therefore, the proposal of "sustainable development" would be an oxymoron (Mastrandrea and Santini, 2013).

\subsection{Water as a motivating theme}

Our study was focused on the needs of education and equal opportunities namely on access to water, convinced that, at the present time, it still remains unawareness about water problems.

"Water is inextricably linked to the development of all societies and cultures. At the same time, this development also places considerable pressure on water resources - agriculture, energy and industry all have impacts on the use and governance of water" (Bokova, 2015, p. v). Therefore, water can be linked with the four pillars of Sustainable Development: social, economic, environmental and political.

Firstly, water is essential for social development. More than half of world population lives in cities and in developing countries many people live in poor conditions and have inadequate water and sanitation facilities. This is the case of a large number of houses and schools of the countries where our research was developed.

In fact, water is indispensable for agriculture, industry and for energy production. In order to improve agriculture and industry is necessary to improve agricultural and industry water management in developing countries, leading to socio-economic development.

On the other hand, degradation of ecosystems causes often bad conditions of water quality.

Finally, political involvement is necessary to improve socioeconomic conditions and this implies the acquisition of knowledge about socioeconomic and environmental aspects, namely water literacy.

Another role of political involvement and active citizenship to achieve sustainable development is their contribution to Disaster Risk Reduction (DRR). In fact, disaster risk is associated with unsustainable elements of development such as environmental degradation, loss of human life, property and consumer goods (United Nations Development Programme and European Commission Humanitarian Office, UNDPECHO, 2010).

One of the greatest causes of poverty in Africa is the lack of access to clean drinking water and consequently one major challenge is the ability for both rural and urban Africans to access a clean water supply.

Water education is consequently a major promoter of Education for Sustainable Development in African countries and consequently for human development. 


\subsection{Education for Sustainable Development (ESD)}

We live in a time and space where most people, particularly young people, are aware of land issues as a common home of a diversity of living beings, social inequalities, interconnections between peoples, knowledge and rapprochement with culture and different cultures. Definitely, we live in the age of the SDGs (Sustainable Development Goals) and on a global scale.

"In this globalized world, with unresolved social, political, economic and environmental challenges, education that helps build a peaceful and sustainable society is essential" (United Nations Educational, Scientific and Cultural Organization, UNESCO, 2017). The content of such education must be relevant, with a focus on both cognitive and non-cognitive aspects of learning. The knowledge, skills, values and attitudes required by citizens to lead productive lives, make informed decisions and assume active roles locally and globally in facing and resolving global challenges can be acquired through ESD. We will focus on teachers' skills in sustainable development as drivers of change in the educational fabric and particularly with their students.

Education for sustainable development is a comprehensive and evolving concept that, in our view, is supported by four socio-cultural, economic, environmental and political (or governance) dimensions. These four dimensions interrelate (see figure 1) and coevolve (Norgaard, 1994) to build a sustainably developed society, inhabiting a healthy planet, and in harmony with all its inhabitants and resources.

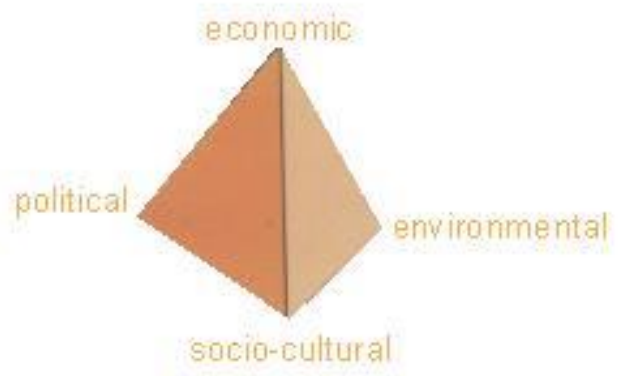

Figure 1: The four dimensions of sustainable development

The essential is the definition of an educational and society strategy. A strategy that seeks to bring the school into society and that requires sharing, seen as a collaborative work structuring of ESD - among all the actors in the training and education processes. This was the challenge assumed in this investigation, as an essay of this collaborative process.

\section{Methodology - Three Case Studies in Portuguese-Speaking African Countries}

The three case studies we will present are based on an ESD community of practice made up of physics and chemistry teachers from six schools in Angola, GuineaBissau, Mozambique and Portugal (Portugal Continental and Azores Islands), who collaborated for two years in the elaboration and application of a water teaching module. Subsequently, it was decided to study further the schools of Angola, Guinea-Bissau and 
Mozambique (figure 2), each constituting a case study on how each teacher developed skills in education for sustainable development.

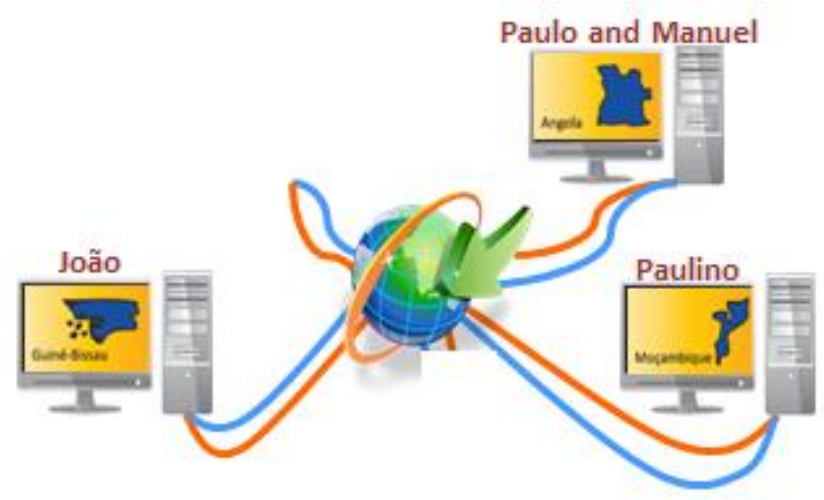

Figure 2: Members of community of practice.

The choice of these three schools is due to the fact that they belong to different socioeconomic backgrounds, located in culturally different countries but, at the same time, with common characteristics such as the Portuguese language and the historical, cultural and political relationship, for several centuries, first belonging to the Portuguese colonial empire and now as countries with multiple economic and cultural relations and members of the Community of Portuguese Speaking Countries (CPLP).

In a global theme, such as education for sustainable development, the research, in different contexts, constitutes an added value.

In the table below (table 1) is showed the characterization of the teachers constituting the community of practice and the schools where they taught at the time of entry into the community (ensuring anonymity of teachers and schools).

Table 1: Characterization of the teachers and schools constituting the community of practice

\begin{tabular}{|c|c|c|c|c|}
\hline 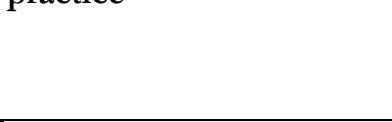 & \multicolumn{2}{|c|}{$\begin{array}{l}\text { Case 1 } \\
\text { Luanda } \\
\text { Angola }\end{array}$} & \begin{tabular}{|c|} 
Case 2 \\
Bissau \\
Guinea Bissau \\
\end{tabular} & \begin{tabular}{|c|} 
Case 3 \\
Maputo \\
Mozambique \\
\end{tabular} \\
\hline Name & Paulo & Manuel & João & Paulino \\
\hline Age & 24 & 26 & 44 & 26 \\
\hline $\begin{array}{l}\text { Academic } \\
\text { Training }\end{array}$ & $\begin{array}{l}\text { 2nd year of } \\
\text { Geophysics }\end{array}$ & \begin{tabular}{|l|} 
Electrical \\
Technician
\end{tabular} & $\begin{array}{l}\text { Bachelor of } \\
\text { Physics and } \\
\text { Mathematics } \\
\text { Teaching }\end{array}$ & $\begin{array}{l}\text { Bachelor of } \\
\text { Chemistry } \\
\text { Teaching }\end{array}$ \\
\hline Years of service & 3 years & 3 years & 25 years & 5 years \\
\hline $\begin{array}{l}\text { Subjects taught and levels of } \\
\text { education }\end{array}$ & $\begin{array}{l}\text { Chemistry } \\
(7 \text { th level) }\end{array}$ & $\begin{array}{l}\text { Chemistry } \\
\text { ( } 7 \text { th level) }\end{array}$ & $\begin{array}{l}\text { Physics } \\
\left(8^{\text {th }}, 9^{\text {th }}, 10^{\text {th }} \text { and }\right. \\
\left.11^{\text {th }} \text { levels }\right)\end{array}$ & $\begin{array}{l}\text { Chemistry and } \\
\text { Biology ( } 8^{\text {th }} \text { and } \\
12^{\text {thlevels})}\end{array}$ \\
\hline Other & $\begin{array}{l}\text { Member of } \\
\text { Directors } \\
\text { Board }\end{array}$ & 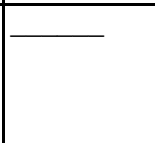 & $\begin{array}{l}\text { Director Assistant } \\
\text { and teacher at } \\
\text { another school in } \\
\text { Bissau }\end{array}$ & - \\
\hline
\end{tabular}




\begin{tabular}{|c|c|c|c|}
\hline School city & Luanda & Bissau & Maputo \\
\hline $\begin{array}{l}\text { Characterization } \\
\text { of school area }\end{array}$ & $\begin{array}{l}\text { Neighborhood on the } \\
\text { outskirts of the city. Lower- } \\
\text { middle-class population } \\
\text { from civil war displaced } \\
\text { people. }\end{array}$ & $\begin{array}{l}\text { Peripheral zone of } \\
\text { the city. Lower } \\
\text { middle class } \\
\text { population. }\end{array}$ & $\begin{array}{l}\text { Noble area of } \\
\text { the city. Upper } \\
\text { middle class } \\
\text { population. }\end{array}$ \\
\hline $\begin{array}{l}\text { Characterization } \\
\text { of the school building }\end{array}$ & $\begin{array}{l}5 \text { classrooms. } \\
\text { Teacher's room. } \\
\text { No lab. } \\
\text { No drinking water. } \\
\text { Small bar. } \\
\text { Small outdoor courtyard. }\end{array}$ & $\begin{array}{l}19 \text { classrooms. } \\
\text { Teachers' room. } \\
\text { Chemistry and } \\
\text { Physics Labs with } \\
\text { some material and } \\
\text { Internet access. } \\
\text { Library. } \\
\text { Wooded area. } \\
\text { Large outdoor } \\
\text { spaces. } \\
\text { Playground }\end{array}$ & $\begin{array}{l}35 \text { classrooms. } \\
\text { Teacher's room. } \\
\text { Chemistry and } \\
\text { physics labs with } \\
\text { some material. } \\
\text { Computer room } \\
\text { (without } \\
\text { equipment). } \\
\text { Library. } \\
\text { Amphitheater. } \\
\text { Canteen. } \\
\text { Pub. } \\
\text { Large outdoor } \\
\text { spaces. } \\
\text { Nurseries and } \\
\text { educational } \\
\text { garden. } \\
\text { Soccer field, } \\
\text { sports hall and } \\
\text { swimming pool. }\end{array}$ \\
\hline Total number of students & 650 students & 1037 students & 4000 students \\
\hline $\begin{array}{l}\text { Average number of students per } \\
\text { class }\end{array}$ & 45 students & 37 students & 60 students \\
\hline Total number of teachers & 25 teachers & 67 teachers & 80 teachers \\
\hline
\end{tabular}

\subsection{The work done in each school}

All teachers had access to various theoretical and pedagogical resources over two years, provided on a purpose-built digital platform. While the community of practice was in operation, the participating members planned, designed and applied to their students an ESD teaching module on drinking water. This module aimed to:

- Raise awareness of water issues, including drinking water;

- Know the physical, chemical and biological properties of drinking water;

- Address issues from a sustainable development perspective;

- Assess the environmental, economic, social and political impact of drinking water problems;

- Propose solutions to water issues taking into account environmental, social, economic and political aspects;

- Promote attitudes of ethical and responsible citizenship.

This drinking water teaching module included experimental activity guides, pre and posttest proposals, and a roll-playing script. Initially the development of this module was a collaborative work where each teacher involved could interact with other teachers, through the digital platform. Nevertheless each teacher applied it differently in their school and performed other activities related to water and sustainable development, not 
established in the module, but adapted to the context in which the school was inserted, or to the possibilities of teachers and schools.

In the end it was proposed to each teacher to elaborate a reflective narrative. This proposal was intended to encourage each teacher to be a reflective professional and a collaborator in their own training (Vicente Rodríguez, 2002), in this case in ESD, exercising this reflective practice in his teaching profession and as a citizen.

For all materials produced in the community of practice an ESD competency model was applied (Sleurs, 2008).

\subsubsection{Case 1 - Luanda}

The technical constraints and access to the digital network did not allow the participation of teachers Paulo and Manuel in the digital platform. Communication and participation in the design and application of the teaching module were therefore compromised. Teachers shared their work by phone, letter and in person (when the researcher went to their school).

Both teachers sought to carry out the experimental activities. They held a debate and a field trip. Initially they promoted a study visit and information gathering on the transportation, storage and use of drinking water in the Huambo district of Luanda, with a consequent report prepared by the students.

The adaptation to the local reality - the water transport companies, so present in the students' daily life, that do not have piped drinking water - led the teachers to develop and successfully apply this field activity to the Huambo neighborhood.

In Chemistry classes, some works on drinking water were elaborated. The test proposals elaborated in the module were the starting point to elaborate some questions in order to a group work.

The following year, the proposed debate took place in the planning of the module. In addition to the two teachers was involved another colleague of the discipline of Chemistry. In the preceding week these three teachers organized the debate and provided the topics to the students. They selected the best students from each class of 7th, 8th and 9th levels from the three shifts of the school (morning, afternoon and evening), totaling about 45 students. The students prepared the debate at home and wrote some papers on water, according to the themes of the debate.

\subsubsection{Case 2 - Bissau}

This school was attended by two teachers at two different times. Initially, professor Samuel, who died victim of illness and, in a second moment, professor João. Technical and personal constraints of Bissau did not allow the access of this teacher to the digital platform. The contacts were made by telephone as well as the sending of paper materials by hand to missionaries residing in that country who knew professor João. They had many difficulties of collaboration.

The reflective narrative was replaced by a questionnaire applied by a well-known missionary of the researcher and professor João.

\subsubsection{Case 3 - Maputo}

Paulino was an active member in the community of practice, and a motivator of 
other colleagues.

In Maputo, the teacher revealed easy access to the Internet. He lived in a city location with better technological and digital access conditions, which facilitated his access to the digital platform and his participation in this project.

At the Maputo school, some lectures on drinking water and sustainable development were taught in the classroom for a year. Paulino also involved several chemistry teachers at the school. At the end of the school year, the test developed in the water module was applied to the whole school.

\subsection{Competences model applied}

"The CSCT project (Curriculum, Sustainable development, Competences, Teacher training) was developed for including education for sustainable development in curricula from pre-school to higher and adult education" (Sleurs, 2008, p. 1). They also tried to offer curriculum models, in ESD, to teacher training institutes.

To improve this competences model, the international group of researchers, were based in the concept that teachers can be professionally developed in three dimensions: as an individual; in relationships with colleagues and students (in the educational institution) and taking part in the society. For all these levels teachers need specific competences, which are explained with the five domains (knowledge, systems thinking, emotions, ethics and values and action). In addition to these, overall competencies are needed: Teaching, Reflecting/visioning and Networking.

In teaching and learning for ESD, all five domains has to be applied to each of the professional dimensions and they also relate to all overall competencies (see figure 3).

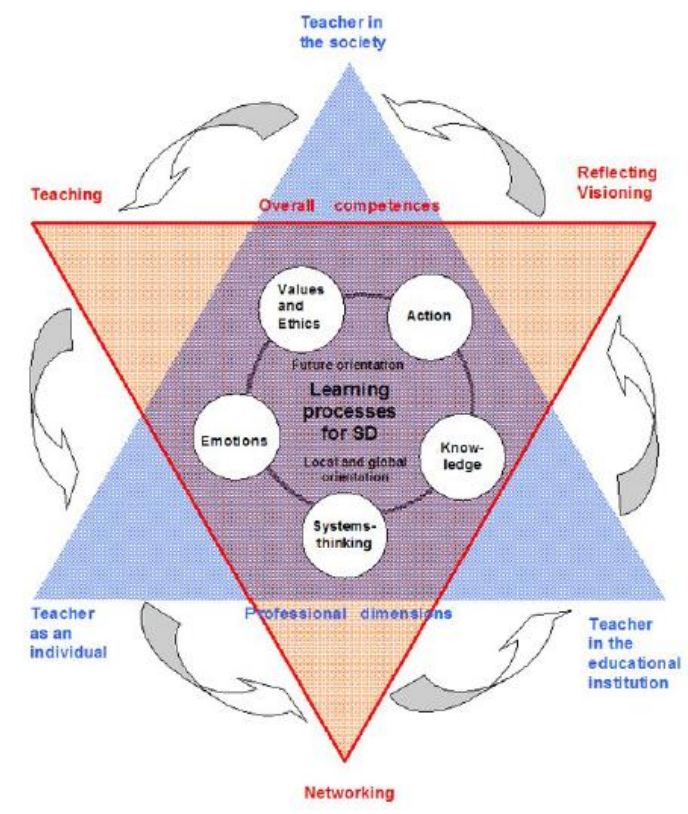

Figure 3: CSCT Model (Sleurs, 2008). 


\section{Outcomes - The Competences Developed in ESD}

\subsection{Case 1 - Luanda}

Paulo and Manuel revealed competencies in several domains, in all professional dimensions.

Teachers Paulo and Manuel revealed competencies in all fields, stand out at the level of "the teacher as an individual - reflection and vision", the skills in the domain of knowledge, values and ethics and action, such as the ability to select educational goals for sustainable development, given the age and school level of their students, relating local and global aspects to each other.

The proposed field study in the Huambo District and the debate held at the school highlighted competences for creating an environment that favors the learning of sustainable development themes or being aware of social tensions. Adding, the teachers, in this activity, revealed competences in the field of action such as the awareness of sustainable development as promoter of individual and social responsibility, and also being able to share responsibility for the teaching process with their students. They also showed the ability to work in broad contexts, not simplifying problems with quick fixes. On the other hand, they presented little evidence (only once) having ability to explain their personal position when civic courage is needed to be demonstrated.

At the level of "the teacher in the educational institution - teaching and communication", skills in the domains of systemic thinking, emotions and action (more than 50\%) are evident. For example look at the various themes from different perspectives taking into account the short and long term consequences.

They also evidenced competences to helping students developing emotional skills (in addition to other competencies) and to be aware of the impact of their choices in a systemic plan. Moreover, competences as finding opportunities for real-world learning processes and skills to organize and facilitate different processes, especially in small groups or in communities, are also demonstrated.

The works I liked the most were those in which the students participated. With their help I realized the great importance of the theme and I realized that it is not only a problem for politicians, but for all of us and so we should all take care of this rich resource, which is indispensable to the life of man. (Professor Paulo)

At the level of "teacher in society - cooperation and networking" were highlighted skills in the field of knowledge, systemic thinking and action. For instance, find collaboration beyond the school community, such as with several organizations promoting the sustainable development. Furthermore, the teacher demonstrated awareness about the school as an integral part of a system, whether at the local, national or global level.

\subsection{Case 2 - Bissau}

Professor João revealed competencies in "Teacher as an individual" and "Teacher in the society". João presented skills at the teacher level as an individual in the field of emotions, developing in him the skills of compassion and empathy and developing a sense of interconnection with the world around him. As well, he is able to act critically in different choices of his daily life.

In addition, at the level "teacher in the society", João was showed competencies in the 
systemic thinking, wisely use existing local, national or international networks in ESD to exchange diverse outlooks. "I hoped I could collaborate on the work, motivate students to learn ways to use drinking water, which is one of our major concerns here in Guinea" (Professor João).

\subsection{Case 3 - Maputo}

Paulino revealed all competencies in domain of emotion and action, in the level "Teacher as an individual". For example persistence and teamwork skills helped him to prove to be one of the most active members.

... Only walking we win! Every fortnight, I will be able to buy an hour of NET to share my experiences in the forum. ... I was pleased with the way the last topics were posted. ... I promise I will do my best. (Professor Paulino)

His persistence and motivation remain present in solving the problematic situation of having burned all the tests performed at school that were the main contribution to community of practice work. It also highlights here the broad problem solving skills and its ability to establish partnerships, in this case communicating the situation, and relying on colleagues to solve it.

At the level of "teacher in the educational institution - teaching and communication", the skills to help students gain plural viewpoints on subjects, to develop critical thinking and to look at various topics from different perspectives taking into account the short and long term consequences, as well as the ability to find opportunities for real-world learning processes, are evident in a test question by Professor Paulino:

Several occasions feature reports on TVM "See Mozambique" program of mothers and children walking 5 to $30 \mathrm{~km}$ looking for water; In the same program it has shown populations that use water from rivers, from ponds created by rain, for consumption without undergoing any treatment; Still in this program, they show the abusive use of water in cities, poorly closed taps, constant ruptures of pipes that carry water, etc. (...) Have you ever thought about how you use water when brushing your teeth, doing your laundry and washing up? What is the relationship between the lack of water pressure in your home and the irregular use of water in your neighborhood?

Finally, at the level "teacher in society - cooperation and networking", it showed the competence to find peers outside the school community and to cooperate with various entities promoting development. Moreover, was revealed a high number of skills in the field of values and ethics (4 out of 5), for example, the aptitude to changing institutional structures within society.

\section{Implications}

We believe that this investigation will raises interest for future projects on watereducation and education for sustainable development, such as:

1 - The follow-up of these three schools.

Did the teachers involved continue to develop their skills in ESD?

Are students in these schools more aware of water issues, where they are located, compared to other schools?

This follow-up could be done with local or online interviews for teachers: and focus group on a water theme with students. 
2 - The theorical review of the pillars of sustainable development

Although it is not within the scope of the case study methodology to generalize its findings, but rather a deeper understanding and interpretation of the specific facts and phenomena (Yin, 2011), in the course of analyzing case studies in contrast to various bibliographic references, the need arises to reformulate part of the conceptual bases of this study presented in Leitão (2012).

The work developed with the teachers was based on the theoretical assumption of four pillars for the sustainable development (economic, environmental, socio-cultural and political). However, as noted by Mastrandrea and Santini (2013) the evolution of the concept of sustainable development reveals that more than pillars, the sustainable development has four areas of action - economic, environmental, social and cultural. The emphasis in the cultural area emerges as important, also in this research, where it can be verified that teachers from different geographical and cultural contexts, produced knowledge, through a collaborative work, applicable to their schools, maintaining the cultural identity of each one place. This leads to consider the need to protect and promote the different cultural environments in a globalized contemporary society.

Given that political and citizenship issues are crucial in sustainable development and $\mathrm{ESD}$, we maintain this dimension as transversal to the four issue areas.

3-Creation of a DRR student club in Maputo school

The Maputo teacher (case 3) showed the most commitment in the community of practice. Especially at the level "Teacher in society - connected with cooperation and networking", he has demonstrated an aptitude for working with colleagues other than his school community as well as with several organizations promoting sustainable development. Therefore, this teacher will be able to apply ESD skills in other related fields, such as DRR education. In fact, DRR may develop mechanisms for resilience to climate change and contribute to poverty decrease that are fundamental subjects in sustainability issues.

Furthermore, Mozambique has an extensive coastline (more than $2700 \mathrm{~km}$ ) with little altitude areas, which makes the country vulnerable to the effects of climate change (UNDP-ECHO, 2010). Indeed, Mozambique is prone to floods, cyclones, and droughts. For example, in 2019, the Tropical Cyclone IDAI made landfall on the night of 14 to 15 March. An estimated 3000 sq. $\mathrm{km}$ of land and 715378 hectares of cultivated land were flooded. At the end of April, more than 1.5 million people have been affected, 400000 had been displaced, over 1600 injured and more than 600 people died. On 25 April, Mozambique experienced a second Tropical Cyclone, Kenneth which made landfall at the end of the rainy season, when river levels were already high, increasing the risk of river flooding (UNDP, 2019).

Not only localized flooding in the rainy season, but also drought, with a periodicity of 3 or 4 years, are natural hazard very commons in Mozambique. Especially in the center and south of the country there are conditions of chronic drought that may have contributed to the death of more than 4,000 people in the last two decades of the 20th century. This situation is due to the impact that drought has on food security and the livelihoods of vulnerable populations.

With these features, it is critical to implement school disaster committees, at all levels in Mozambique. At school level, for instance, the most strategic approach would be to raise 
teachers' awareness in DRR and sustainable development. These teachers could be developing extra-curricular activities such as school assemblies, after-school clubs and competitions in such issues (UNDP-ECHO, 2010).

\section{References}

Bokova, I. (2015) Foreword. In: United Nations World Water Assessment Programme, WWAP. The United Nations World Water Development Report 2015: Water for a Sustainable World. UNESCO, Paris.

Leitão, M. (2012). A constituição e o funcionamento de uma comunidade de prática de professores em educação para o desenvolvimento sustentável (Doctoral Thesis. Open University. Lisbon.

Mastrandrea, F. and Santini, F. (2013). Education for Sustainable Development. A tool to design training courses. Lecce-Brescia: Pensa Multimedia.

Norgaard, R. (1994). Development betrayed: The end of progress and a coevolutionaryr evisioning of the future. London: Routledge. http://books.google.co.uk/books?id=sZqSuOsqq4cC\&pg=PA21\&hl=pt-

PT\&source $=$ gbs_toc_r\&cad $=4 \# \mathrm{v}=$ onepage\&q\&f $=$ false Accessed June 2019

Sleurs, W. (Ed.). (2008). Competencies for ESD (Education for Sustainable Development) teachers. A framework to integrate ESD in the curriculum of teacher training institutes. Comenius 2.1 project 118277-CP-1-2004-BEComenius- C2.1. Bruxelas: ENSI, CSCT e SÓCRATES. http://www.unece.org/fileadmin/DAM/env/esd/inf.meeting.docs/EGonInd/8mtg/CSCT\%20 Handbook_Extract.pdf. Accessed June 2019

United Nations Development Programme, UNDP (2019). Mozambique Cyclone Idai - Post Disaster Needs Assessment.

https://www.undp.org/content/dam/undp/library/Climate\%20and\%20Disaster\%20Resilience/ PDNA/PDNA\%20Mozambique\%20Cyclone\%20Idai\%20-\%20Post-

Disaster\%20Needs\%20Assessment_Executive\%20Summary.pdf. Accessed October 2019

United Nations Development Programme and European Commission Humanitarian Office, UNDP-ECHO (2010). Community-based best practices for Disaster Risk Reduction https://www.undp.org/content/dam/mozambique/docs/Community\%20based\%20BP.pdfAcce ssed 20 October 2019

United Nations Educational, Scientific and Cultural Organization, UNESCO (2017). Education for Sustainable Development and Global Citizenship in Education 2030/SDG 4. https://bangkok.unesco.org/content/education-sustainable-development-and-global-citizenshipeducation-2030-sdg-4. Accessed 20 October 2019

Vicente Rodríguez, P. (Dir.) (2002). Desarrollo profesional del docente: En un modelo evaluativo de colaboración. Bilbao: ICE-Universidade de Deusto.

Yin, R. (2011). Qualitative Research from Start to Finish. New York, London: The Guilford Press. 